\title{
Experiences of Disengagement - A Study of Doctoral Students in the Behavioral Sciences
}

\author{
Jenna Vekkaila, Kirsi Pyhältö, and Kirsti Lonka \\ University of Helsinki, Helsinki, Finland \\ jenna.vekkaila@helsinki.fi; kirsi.pyhalto@helsinki.fi; \\ kirsti.lonka@helsinki.fi
}

\begin{abstract}
Doctoral students are a highly select and skilled group due to their academic backgrounds. However, pursuing a $\mathrm{PhD}$ is always a challenging journey. Previous research suggests that while many find their doctoral process rewarding, a number of doctoral students face serious problems. Such problems often originate from the relation between the doctoral student and the scholarly community. This study explored doctoral students' experiences of disengagement from their doctoral processes. Altogether 16 behavioral sciences students, who had prolonged $\mathrm{PhD}$ processes, were interviewed. The data were collected with semi-structured interviews and were qualitatively content analyzed. The study provides new insights into doctoral education by shedding light on varying forms of students' disengagement ranging from experiences of inefficacy to cynicism and sometimes exhaustion. The study also demonstrates how activities that trigger disengagement have typically included struggles and conflicts within the scholarly community. Problems in the research itself were less frequently found to be the main source of disengagement. Variation was also noted in the quality of the destructive dynamics between the students and their environments that contributed to the students' disengaging experiences.
\end{abstract}

Keywords: behavioral sciences, doctoral experience, doctoral research, doctoral studies, student-environment misfit, scholarly community, student disengagement.

\section{Introduction}

Pursuing a $\mathrm{PhD}$ is always a highly inspiring and challenging journey. Earlier research on the doctoral experience has shown that while many students find their doctoral process rewarding, some face serious challenges including personal sacrifices, intervening life experiences, departmental problems, lack of support, difficulty in completing the dissertation, as well as a lack of funding (Appel \& Dahlgren, 2003; Jairam \& Kahl Jr., 2012; Protivnak \& Foss, 2009; Spaulding \& Rockinson-Szapkiw, 2012). For instance, Lee (2009) found that nursing students enrolled in doctoral studies perceived multiple responsibilities, financial issues, difficult relationships with faculty

Material published as part of this publication, either on-line or in print, is copyrighted by the Informing Science Institute.

Permission to make digital or paper copy of part or all of these works for personal or classroom use is granted without fee provided that the copies are not made or distributed for profit or commercial advantage AND that copies 1) bear this notice in full and 2) give the full citation on the first page. It is permissible to abstract these works so long as credit is given. To copy in all other cases or to republish or to post on a server or to redistribute to lists requires specific permission and payment of a fee. Contact Publisher@InformingScience.org to request redistribution permission. members or advisors, as well as a lack of academic self-discipline and negative academic self-image as detracting factors in their study process.

The challenges provided by doctoral studies are not necessarily negative; in fact, solving complex ill-defined problems can be seen as essential to creating new knowledge. At best, such challenges can be positive forces that en- 
courage students to progress in their doctoral process. They may, however, also become stressors if adequate support is not given to the student. At worst, they can become insurmountable obstacles that lead to delays or even dropping out from doctoral studies. Some evidence shows that problems in doctoral studies often originate not from the research process itself but from the relation between the doctoral student and the scholarly community (Pyhältö, Stubb, \& Lonka, 2009). For instance, doctoral students' experiences of social isolation from their scholarly communities, with respect to overlapping communities, groups of supervisor-students dyads, other senior researchers, or academics within and across departments, faculties, or institutions (Ali \& Kohun, 2006; Lovitts, 2001), and mismatches between students' expectations and those of the community, have been suggested to cause withdrawal from doctoral studies (Golde, 2005; Hoskins \& Goldberg, 2005; Tinto, 1993). Moreover, there is also evidence of doctoral students often experiencing reduced wellbeing and distress while pursuing their PhDs (Hyun, Quinn, Madon, \& Lustig, 2006; Kurtz-Costes, Helmke, \& Ülkü-Steiner, 2006), and a remarkably high number of students, $30-50 \%$ or even more in different contexts and countries, decide to leave their studies (Golde, 2005; McAlpine \& Norton, 2006).

Previous studies on the doctoral experience have provided information about factors associated with students' persistence, time-to-the-doctorate, and attrition (Golde, 1998, 2005; Hoskins \& Goldberg, 2005; Lovitts, 2001; Tinto, 1993; Wao \& Onwuegbuzie, 2011). Moreover, there is an extensive body of literature on disengagement among undergraduate students (Pekrun, Goetz, Frenzel, Barchfeld, \& Perry, 2011; Salanova, Schaufeli, Martı'nez, \& Bresó, 2010; Schmitt, Oswald, Friede, Imus, \& Merritt, 2008; Schreiner, Noel, Anderson, \& Cantwell, 2011) as well as among employees in work settings (Demerouti, Bakker, Nachreiner, \& Schaufeli, 2001; Hakanen, Bakker, \& Schaufeli, 2006; Schaufeli, Salanova, González-Romá, \& Bakker, 2002). However, little is known about what disengages (and ultimately withdraws) doctoral students from their studies and the kinds of episodes that are associated with disengagement. Accordingly, there is a need for a better understanding of the nature of the experiences that reduce doctoral student engagement during the doctoral process and the dynamics that contribute to disengagement. Analyzing these disengaging episodes will make it easier to identify the central developmental objectives in doctoral education. This may help to prevent the disengaging experiences that may be associated with delays and even students abandoning their doctoral studies. The present study focuses on exploring doctoral students' experiences of disengagement from the doctoral process in various environments within and outside academia.

The paper begins with a literature review that focuses on doctoral students' disengagement and student-environment interaction. Second, the methods section (including a brief contextual overview of the Finnish doctoral education system) and the results are presented. Lastly, conclusions regarding the results are provided and implications for research and practice are discussed.

\section{Disengagement and the Doctoral Student-Environment Interaction}

Conducting doctoral research can be reflected on in terms of both academic work and studying. Doctoral students take their first steps as professional researchers by carrying out doctoral research and teaching undergraduates, which can be considered academic work (Brew, Boud, \& Namgung, 2011; Golde, 1998; Turner \& McAlpine, 2011). However, doctoral students also take courses (Baker \& Lattuca, 2010; Brew et al., 2011; Golde, 1998; Turner \& McAlpine, 2011). Due to this duality, our study draws on research into both reduced work engagement (Schaufeli et al., 2002) and study engagement (Fredricks, Blumenfeld, \& Paris, 2004).

Disengagement refers to student's passivity with regard to a task or an activity at hand (Fredricks et al., 2004; Reeve, Jang, Carrell, Jeon, \& Barch, 2004), including distancing oneself from one's 
work and experiencing negative emotions toward the work in general (Demerouti et al., 2001; Schaufeli et al., 2002). Accordingly, doctoral student disengagement refers to withdrawal and passivity with regard to the various learning opportunities and practices provided by students' scholarly communities. Disengagement is characterized by low energy, reduced involvement, and experiences of inefficacy (Maslach, Schaufeli, \& Leiter, 2001; Schaufeli et al., 2002). Low energy refers to feeling strained and exhausted resulting from experiencing one's work as overly demanding (Schaufeli et al., 2002). Reduced involvement, on the other hand, refers to losing interest in one's work and feeling that the work has lost its meaning, while inefficacy is characterized by a sense of being incompetent in one's work (Schaufeli et al., 2002). At its worst, disengagement may develop into burnout consisting of all the three elements (Maslach et al., 2001). Studies suggest that disengagement has several outcomes such as lower levels of commitment (Hakanen et al., 2006) and achievement (Carini, Kuh, \& Klein, 2006; Fredricks et al., 2004), as well as more turnover intentions (Fredricks et al., 2004; Schaufeli \& Bakker, 2004). Hence, disengagement may prevent doctoral students from being energetically involved in an effective and meaningful doctoral process.

Disengagement always develops in the dynamic interplay between individuals and their environments (Demerouti et al., 2001; Fredricks et al., 2004; Lindblom-Ylänne \& Lonka, 2000; Schaufeli et al., 2002). For doctoral students the primary learning and working environment is the scholarly community (Gardner, 2007; McAlpine \& Amundsen, 2008). However, this community itself is a complex, multilayered, and nested entity (McAlpine \& Norton, 2006) that can be identified by components ranging from 'abstract' disciplines to specific research groups (Tinto, 1993; White \& Nonnamaker, 2008). For instance, building on previous research (Bozeman, Dietz, \& Gaughan, 2001; Levine, 2007; Lovitts, 2005), Leech (2012) presented a model of the complexity of educating skilled and knowledgeable researchers that includes multiple areas of importance, such as individual resources, program characteristics, faculty members, and location as well as the culture of a discipline and its graduate education. It follows that the community provides various arenas in which students can participate. Even within a single week, doctoral students might work with peers, members of the professional community, as well as undergraduate students and hence be involved in a variety of the scholarly community's practices (Brew et al., 2011; Holley, 2011). This means that doctoral students are not influenced only by the scholarly community; they can, at least to some extent, actively choose the primary arenas in which to participate (McAlpine, Jazvac-Martek, \& Hopwood, 2009; O’Donnell, Tobbell, Lawthom, \& Zammit, 2009). They can, for instance, ignore some practices, adapt to or adopt other practices, or even leave the community entirely (Pyhältö \& Keskinen, 2012). Moreover, the practices themselves are constantly evolving within numerous interactions (Lave \& Wenger, 1991). Hence, both the practices and student participation are constructed and renegotiated in person-environment interactions (Lave \& Wenger, 1991). This means that in certain arenas doctoral students can be active and have central positions whereas in others they may be more peripheral. Furthermore, pursuing a $\mathrm{PhD}$ may take place not only in complementary or rival communities of practice but also beyond academia in conjunction with students' professional or family lives (Appel \& Dahlgren, 2003; Gardner 2007; Protivnak \& Foss, 2009).

One way to break down the complex dynamics that contribute to doctoral students' disengagement is to explore them in terms of person-environment fit (Edwards, Cable, Williamson, Schurer Lambert, \& Shipp, 2006). This framework builds on Holland's (1985) seminal work on the JobFit Model. Fit refers to the congruence between individuals and their environment (Edwards et al., 2006; Kristof, 1996), and, accordingly, misfit refers to a lack of congruence. Studies have indicated that the perceived misfit between doctoral students and their working environment is negatively associated with students' doctoral experience including their completion of the process (Gardner, 2007; Tinto, 1993). For instance, Hoskins and Goldberg's (2005) study of current and former doctoral students revealed that if students experienced a negative relationship with faculty 
and peers, or that if the focus of their doctoral program was not in line with their goals, they questioned their continuation in the training. In line with this, Golde (2005) found that doctoral students associated misfits between their goals and expectations as well as the norms and practices of their discipline and department with their own willingness to persist. A perceived misfit in the supervisory relationship has also been suggested to cause dissatisfaction and problems (Golde, 1998; Ives \& Rowley, 2005; Jairam \& Kahl Jr., 2012; Lovitts, 2001). Golde's (2005) research, for instance, indicated that a misfit between students' and advisors' thinking and working styles was one of the reasons for student attrition. This suggests that destructive friction between the environment and the learner (Lindblom-Ylänne \& Lonka, 2000; Vermunt \& Verloop, 1999), such as lack of congruence between doctoral students' and their environment's working practices or perceptions of work requirements, as well as lack of support or locus of control, are likely to cause a misfit. Clearly, perceived misfits may result in disengagement (Hakanen et al., 2006; Schaufeli \& Bakker, 2004).

Recent research into the doctoral experience has also revealed the significance of belonging to a scholarly community (Ali \& Kohun, 2006; Deem \& Brehony, 2000; Lovitts, 2001, Spaulding \& Rockinson-Szapkiw, 2012) with respect to disengagement. For instance, Tinto (1993, p. 230-243) applied his model also to doctoral students by claiming that their persistence can be understood in terms of experiences of integration into the social and academic life of the institution and the various intersecting communities within or outside academia. He suggested that high levels of integration reinforce commitment to the institution and to the goal of completing a degree, which in turn leads to actual degree completion. On the other hand, poor integration often arises from two sources: incongruence, i.e., a mismatch between the student and the institution, and social isolation, i.e., insufficient interaction with faculty or other academic communities. In line with this, Pyhältö et al. (2009) found that more than half of the participants perceived themselves as members of the scholarly community, about a third saw themselves as outsiders, while the rest had an incoherent perception of their status. More recent studies have shown that doctoral students who experienced their scholarly community in a negative way (i.e., who perceived it to be a burden or perceived themselves as passive objects) more often reported a lack of interest in their studies, and more often considered interrupting them, than students who had empowering experiences or who considered themselves to be active agents in their scholarly communities (Pyhältö \& Keskinen, 2012; Stubb, Pyhältö, \& Lonka, 2011). This implies that disengagement is highly embedded in a lack of participation, or destructive social relations, in the scholarly community.

\section{Aims}

The study aimed at gaining a better understanding of the kinds of experiences that according to students disengaged them from their doctoral process. The following research questions were addressed:

(1) What forms of disengagement can be identified among doctoral students in the behavioral sciences?

(2) What kinds of activities can be identified as contexts for doctoral students' disengaging experiences?

(3) What are the various dynamics between doctoral students and the contexts of disengaging situations?

The study is part of a larger national research project on doctoral education in Finland that aims to better understand the process of PhD education (Pyhältö et al., 2009). 


\section{Method}

A qualitative approach was applied (Marshall \& Rossman, 1995; Miles \& Huberman, 1994) to explore doctoral students' experiences of disengagement from their doctoral process and variations in these experiences. Our methodological approach was inspired by a phenomenography that focuses on the variation in people's ways of experiencing the phenomenon under study (Marton, 1986; Van Rossum \& Hamer, 2010).

\section{Doctoral Education in the Finnish Context}

Doctoral studies in Finland focus heavily on conducting research, and course work is not emphasized. A doctoral degree includes a doctoral thesis, seminars, course work, and public defense of the thesis. No extensive separate course work need be completed before launching into doctoral research. Course work (from 40 to 80 European Credit Transfer and Accumulation System credits (ECTS) depending on the discipline) included in doctoral studies is usually individually designed to support the thesis project and based on personal study plans.

Doctoral theses can be done either in the form of a monograph or as a series of articles including a summary (Finland's Council of State's regulation for university degrees 645/1997). In the behavioral sciences, an article compilation with a summary has become the dominant form $(66 \%)$ in recent years (Pyhältö, Stubb, \& Tuomainen, 2011). This type of dissertation consists of three to five internationally refereed journal articles co-authored with the supervisor and other senior researchers, as well as a summary that includes an introduction and a discussion bringing together the separate articles. Doctoral students who pursue monographs often engage in seminars, and supervision is based on supervisor-student dyads rather than intensive work in research groups. Doctoral supervision is, however, usually based on an apprenticeship, in both the research groups and supervisor-student dyads.

The average time to complete a doctoral degree in the behavioral sciences is from six to over ten years (Pyhältö et al., 2011; Sainio, 2010). Doctoral education is publicly funded and therefore free, but students must pay for their living expenses, usually from personal grants, project funding, or wages from work outside the university (Pyhältö et al., 2011).

\section{Participants}

The study's participants were selected from a follow-up register of doctoral students who were contacted by their faculty because their doctoral processes were prolonged. Our presumption was that disengaging experiences could be more frequently reported among these students. The annual postgraduate study follow-up register contains registered doctoral students whose admission to postgraduate studies has exceeded seven years from the end of the preceding academic year and whose doctoral studies are unfinished. These students cannot register themselves as undertaking studies until their revised personal study plans have been accepted by their faculties (Decision of vice-chancellor 234/2006). The register follow-up aims to encourage doctoral students to complete their degrees and to provide them with support and supervision (Decision of vice-chancellor 6/2011).

The participants were 16 behavioral sciences (educational sciences, psychology and cognitive science, speech sciences) doctoral students (female: 11, male: 5; mean age: 45 years) from a major research-intensive Finnish university. All participants were doctoral students at the time of the interviews: three full-time, eight part-time, and five a combination of both. Seven participants were doing a monograph and six a summary of articles, while the remaining three were unsure of the form their theses would take. Seven were pursuing their doctoral theses both alone and in a group, five alone, and four in a group. The participants had been engaged in their doctoral studies 
for seven or more years. All had master's degrees, and they were at different stages of the doctoral process. The participants were interviewed on a voluntary base.

\section{Interviews}

Disengaging experiences were explored by conducting semi-structured interviews (Kvale, 1996, 2007) in the spring of 2010. A phenomenography-inspired approach was applied to gain a better understanding of the students' experiences and their perspectives on disengagement. The semistructured interviews made it possible to reveal such experiences (Kvale, 1996, 2007). The interview procedure was designed to capture the significant positive or negative episodes (i.e., events and situations) encountered by the students during their doctoral journey, and how they experienced them (Vekkaila, Pyhältö, Hakkarainen, Keskinen, \& Lonka, 2012). Our exploration focused on the negative, challenging, and disengaging experiences described by the students. The interviews also addressed background questions such as length and phase of doctoral studies as well as form of thesis.

The interview procedure, i.e., the questions and instructions, were tested and modified in a twophase pilot study before conducting the interviews. In the first phase (autumn 2008) we conducted a pilot study with six behavioral sciences doctoral students. Following this we modified the interview questions and instructions in a research group that consisted of us as well as one professor and a doctoral student from the faculty from which the participants in the present study were selected. The second pilot interviews were carried out at the beginning of 2009 with two other behavioral sciences doctoral students.

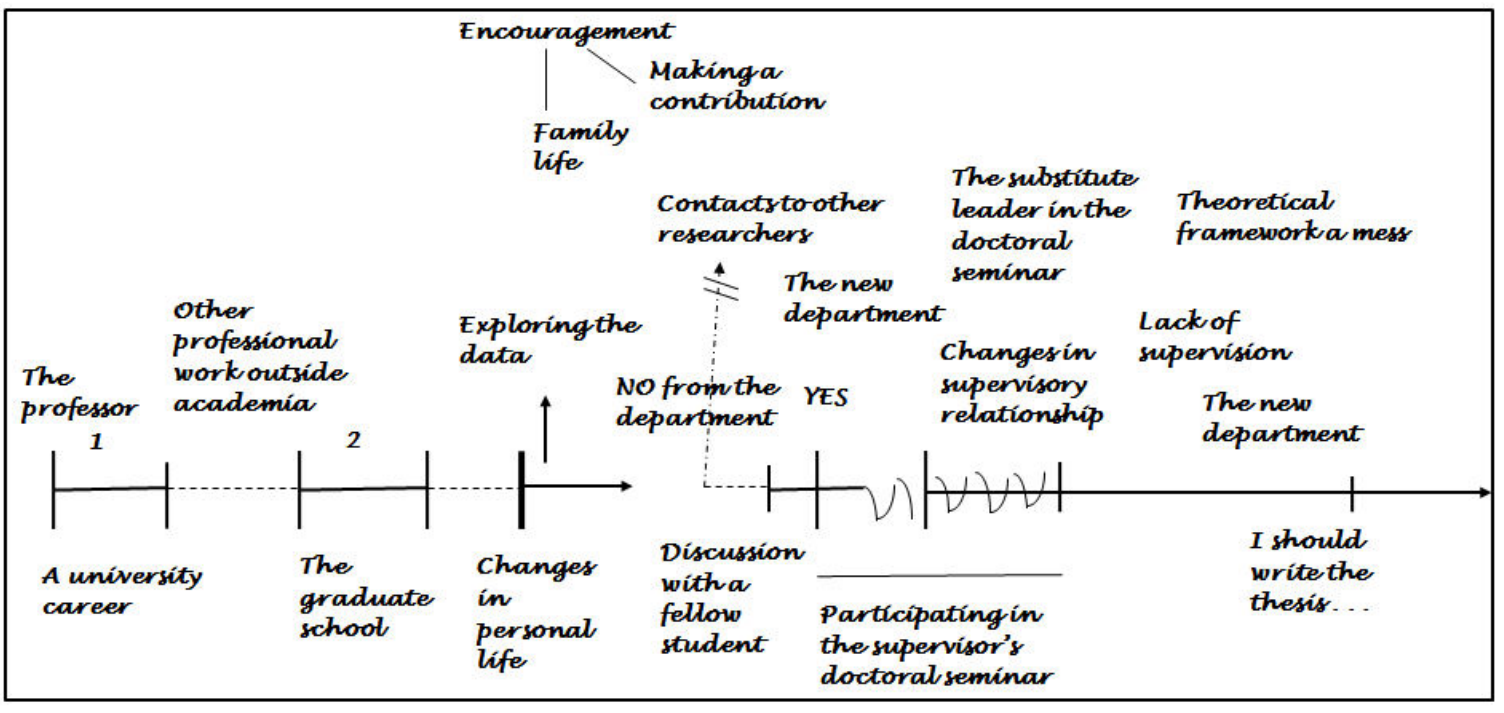

Figure 1: An example of a typical representation of the doctoral process (reconstructed, all identifying information removed). Positive and negative experiences were discussed in the interviews.

In the interviews, participants were first asked to visualize their doctoral journey on a piece of paper. For instance, the students drew their journeys as time lines, winding roads or maps. Figure 1 provides a typical example of such a visualization. Then the students were asked to identify and mark the positive, promoting episodes as well as negative, hindering ones in the visualizations. Facilitating reflection on such experiences can be difficult in traditional interviews, hence visualization-based interviews (Reavey, 2011; Rose, 2007) were used to prompt students to reflect on the events. Following this, the participants were interviewed based on their visualizations. They were asked to describe their experiences one episode at a time. They were also asked to elaborate 
on their descriptions when necessary by answering questions such as 'When and where did the episode in question occur?', 'Why did the episode occur?', 'What were you thinking during the episode?', 'What happened after the episode?' and 'What other persons or groups, if any, were involved in the episode?'

To encourage a closer sharing of personal experiences the interviews were conducted by the first author who was also a doctoral student. Before conducting any of the interviews she had attended an interview training session which focused on questioning techniques, active listening, and interviewer-interviewee interaction. The interviews were recorded and lasted on an average of one hour and 46 minutes (ranging from 50 to 150 minutes). The interviews were transcribed by a trained research assistant.

\section{Analysis}

The analysis aimed at identifying doctoral students' experiences of disengagement from the doctoral process and variations in such experiences. The interview data were qualitatively content analyzed using an abductive strategy (Coffey \& Atkinson, 1996; Haig, 2005; Levin-Rozalis, 2004; Morgan, 2007). Hence, in each phase of the analysis process the researchers moved back and forth between data observations and prior understanding based on the theory when categorizing the data (Coffey \& Atkinson, 1996). In addition, the observations and theories were repeatedly assessed in relation to each other in order to acquire the most optimal understanding of the phenomenon (Haig, 2005; Levin-Rozalis, 2004; Morgan, 2007), i.e., disengagement from the doctoral process, as described by the students. In line with ideas from phenomenography, the analysis focused on variations in participants' experiences of a certain phenomenon (Marton, 1986; Van Rossum \& Hamer, 2010). Accordingly, all the categories were formed based on similarities and differences in the participants' experiences of the phenomenon (Brew, 2001; Akerlind, 2005). The analytical strategy was an adaptation of the analysis procedure developed and used by Pyhältö, Pietarinen, and Salmela-Aro (2011) in their research on teacher burnout.

The analysis included four phases (see Figure 2). First, a grounded analysis (Harry, Sturges, \& Klingner, 2005; Mills, Bonner, \& Francis, 2006) was applied to capture the students' experiences of disengagement. Accordingly, the analysis was experience-oriented. The interviews were read through several times to obtain an overall understanding of the students' experiences. Then, all text segments where the students referred to disengagement from their doctoral process were coded into the same hermeneutic disengaging episodes category. These references included disappointments, prolonged problems, academic failures, negative emotions related to the doctoral process, lack of productivity in the doctoral work, becoming passive, diminishing possibilities to conduct the doctoral work, and lack of energy.

In the second phase the analysis was more theory-guided (Patton, 1990) and relied on existing knowledge and prior studies concerning disengagement (Maslach et al., 2001; Schaufeli et al., 2002). The text segments in the disengaging episodes category were divided into categories following the idea that the text segments in one category were similar to each other while being distinct enough from the other categories. As a result, three exclusive main categories were formulated: (a) inefficacy, (b) cynicism, and (c) exhaustion, which reflected the three main forms of disengagement described by the students.

In the third phase we again relied on a grounded analysis (Harry et al, 2005; Mills et al., 2006) and explored the various forms of disengagement from the doctoral process in terms of the activities in which students situated their experiences. By focusing on the differences and similarities in regard to the activities, the main forms of disengagement were coded into the basic categories: 
(1) struggles and conflicts within the scholarly community, including dealing with inconsistent requirements of academic assignments or research as well as problematic encounters and negative interaction with other researchers,

(2) tensions in the supervisory relationship, such as receiving insufficient supervision or destructive feedback from a supervisor,

(3) problems in the research process, such as obstacles to collecting data and writing papers,

(4) balancing doctoral studies with family and professional work life, including lack of support, high workload, and changes within the family.

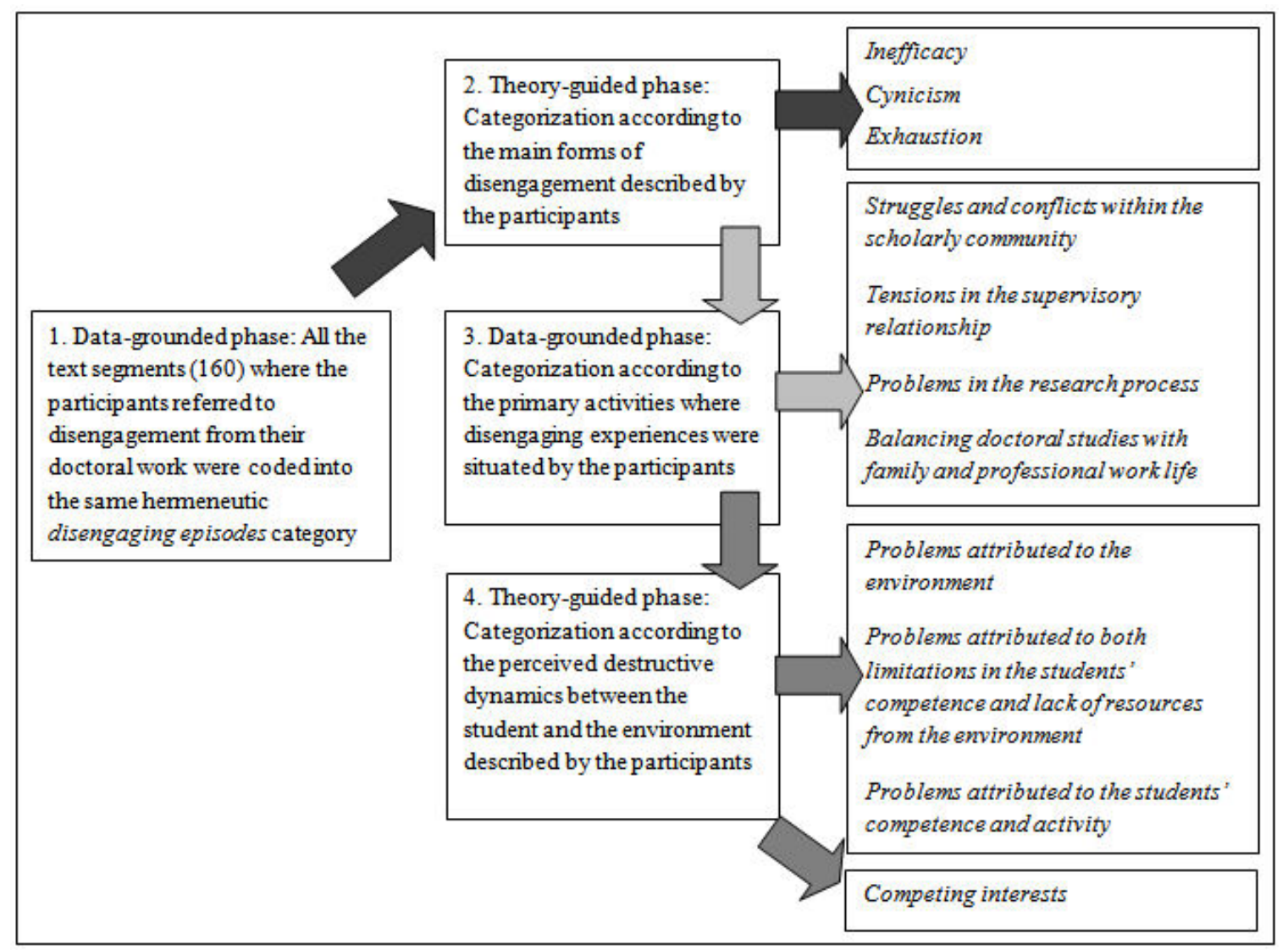

Figure 2: A visualization of the analysis process.

The fourth phase of the content analysis was theory-guided (Patton, 1990) and explored various forms of disengagement from the doctoral process in regard to the nature of the dynamics between the student and the context in each episode. Accordingly, this phase relied on existing knowledge and prior studies concerning person-environment fit (Edwards et al., 2006; Kristof, 1996). In this phase the primary activities of disengagement were coded into sub-categories according to the similarities and differences in the perceived destructive dynamics between the student and the environment due to the following:

(I) problems attributed to the environment: this sub-category included disengaging episodes where the students identified the problem that caused a misfit in the dynamics as originating from lack of support or unclear requirements from the environment,

(II) problems attributed to both limitations in the students' competence and lack of resources from the environment: this sub-category included disengaging episodes where the students identi- 
fied the problem that caused a misfit in the dynamics as originating from their perceived limitations in their own competence or other personal resources as well as lack of support and other resources from the environment,

(III) problems attributed to the students' competence and activity: this sub-category included disengaging episodes where the students identified the problem that caused a misfit in the dynamics as originating from their perceived limitations in their own competence or other personal resources.

In addition, competing interests due to other more attractive possibilities in the family or professional life were described. This category did not include destructive dynamics between the student and the environment.

In the analysis process, the data and the theories were continuously checked for any reasons why the interpretations should or should not be trusted, which in turn was likely to affect the validity of the findings (Kvale, 2007). The ecological validity of the findings (Bryman, 2004; Creswell, 2003), i.e., their communicative validity (Kvale, 2007), was tested during a Faculty Committee meeting that focused on postgraduate studies. During the meeting the findings were reflected on by the committee members after they had been introduced to the results in a presentation given by the first author. In the Results section we provide direct quotations of the participants' descriptions, translated from Finnish to English.

\section{Results}

The results suggest a variation in the students' experiences of disengagement from their doctoral process. The nature of the described inefficacy, cynicism, and exhaustion experienced by the students ranged from disappointing episodes to serious fatigue. In addition, disengagement was revealed through episodes that varied from brief single events, such as a particular seminar session, to longer situations, such as constant and prolonged problems in interactions with the faculty. Moreover, the form in which the students expressed their disengagement altered from feeling inadequate or overburdened to becoming cynical. All students described varying experiences of disengagement, and hence the frequencies provided in the following sections are based on all of the 16 interviews and 160 disengaging episodes described by the participants together.

\section{Forms of Disengagement}

The doctoral students emphasized their experienced inefficacy $(44 \%, 71 / 160)$ as students and novice researchers (see Table 1). They perceived that the work and effort that they had put into their research and theses were insufficient. They also expressed uncertainty relating to pursuing their research and a lack of courage to continue. They felt that they lacked self-efficacy and that they were ineffective in pursuing their work. Hence, their perceptions of themselves as being capable of conducting the doctoral work were diminished. For instance, as one of the students described:

The other advisor was there in the seminar but the attitude was like "Well, this is nonsense again" and for me this situation formed an impediment...I felt lousy and very incompetent in what I was doing. I was uncertain about my work...Then somehow the work just drifted away, I did not know how to proceed and felt like this was not going to work out.

The students also highlighted cynicism $(42 \%, 66 / 160)$ with regard to their doctoral process. They described having no control over the process as well as apathy and being disinterested in the research and their progress in it. They felt that their doctoral work had lost its meaning and importance. In addition, they experienced alienation from the doctoral process due to insufficient time 
to conduct the research and write the thesis and, hence, a gap opened between them and their pursuit of a PhD. As one of the students shared:

Then I started my other work, and in a sense I developed a feeling that it was impossible to conduct the research work. For my doctoral thesis this was a very, negative critical thing... When you carry that research long enough in your mind you start to wonder whether you want to do the thesis anymore...

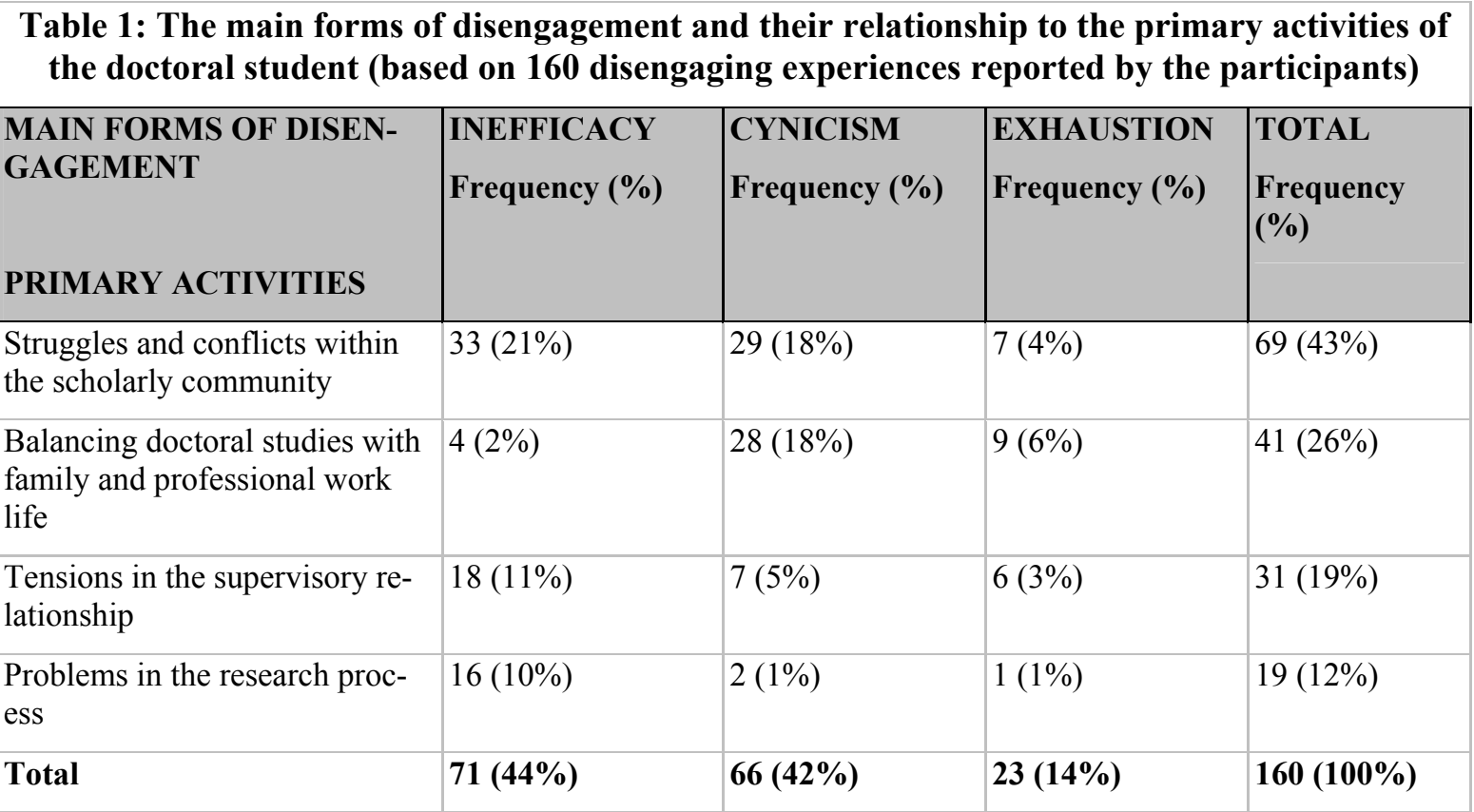

The students seldom described experiences of exhaustion $(14 \%, 23 / 160)$. When they did, it was in terms of feeling overstrained and having no energy to continue. Sometimes the students were fully exhausted or even depressed, and consequently had distanced themselves from their doctoral work and postponed it. As one student described:

Then little by little I became depressed and it took control of me. I had done a lot of work for my thesis, and then I felt like I was not able to do it at all, that I would quit this whole thing...I was quite depressed and I wanted to distance myself from my thesis.

Variation was also expressed in the situations and activities that the doctoral students identified as contributing to these disengaging experiences. However, the experiences were often related to problematic interactions within the scholarly community.

\section{Activities Relating to Disengagement}

We found that the disengagement experienced by the students was associated with the four primary activities of their doctoral work. However, the way in which the experienced disengagement was manifested in the students' descriptions varied. The students emphasized struggles and conflicts within the scholarly community $(43 \%, 69 / 160)$ as being the primary activity triggering disengagement from the doctoral process (Table 1), looking at the rows, instead of the columns). In their experiences, dealing with inconsistent requirements of the national and international research communities, finding themselves in the middle of community conflicts as well as problematic interactions with other researchers and an oppressive academic atmosphere, for instance 
rude treatment and destructive feedback, fed the students' sense of inefficacy and cynicism. As one of the students described:

I had the first thoughts of starting this work and then I felt that I was treated very badly by the department. I felt that the attitude was "You are from yesteryear, we won't invest in you”... Then I was very down, I thought that this thesis was not going to work out.

In addition, the students highlighted balancing doctoral studies with family and professional work life $(26 \%, 41 / 160)$ outside academia as triggering their disengagement. A heavy workload and the demands of full-time work or family responsibilities reduced the students' time for their studies, and hence they became alienated from their doctoral process. As one student remarked:

Here at this point I tried but was not able to conduct the research work at all, except for on a few weekends. I work long hours in my full-time work, I was tired, and this took all my energy. I always had the feeling that I should work and do more in a day than I was able to. I tried to do my best.

The students sometimes mentioned that facing tensions in the supervisory relationship $(19 \%$, 31/160) triggered their disengagement. Inadequate supervision such as a lack of support, destructive feedback, power games, or bullying as well as a complete lack of supervision led them to feelings of inefficacy. As one student shared:

My supervision situation was totally disastrous. It was hard, I almost quit several times ...There was no doubt that I was bullied. I got disrespectful messages from the supervisor...For instance, my supervisor just cancelled my opportunities to participate in conferences, which were essential because I could have received feedback there...

The students infrequently reported that their disengagement was triggered by problems in the research process $(12 \%, 19 / 160)$. Obstacles in the data collection and analysis, challenges in writing and publishing papers, or demanding research requirements and workloads were typically described as elements of the research process that promoted a sense of inefficacy. As one student commented:

Then my intention was to analyze the data but I felt quite disappointed...I felt that I should have been able to...I should have started the work right away but somehow I was not competent enough to do that.

\section{The Dynamics of Disengagement}

We also explored the doctoral students' perceptions of the relationship between themselves and the primary activities of their disengaging experiences.

The students emphasized their disengagement to be the result of a perceived misfit between themselves and their environment $(91 \%, 146 / 160)$. However, a variation was noted in the misfit (see Figure 3). The students emphasized $(52 \%, 84 / 160)$ their disengagement to be the result of an alienating or overly controlling environment. They sometimes also felt that both their own efforts and the support from the environment were insufficient, and hence they became disengaged $(22 \%, 35 / 160)$. Only sometimes did the students describe not being as competent or active as they should have been in terms of meeting the requirements of the environment $(17 \%, 27 / 160)$. Moreover, they rarely associated their disengagement with competing interests $(9 \%, 14 / 160)$. 


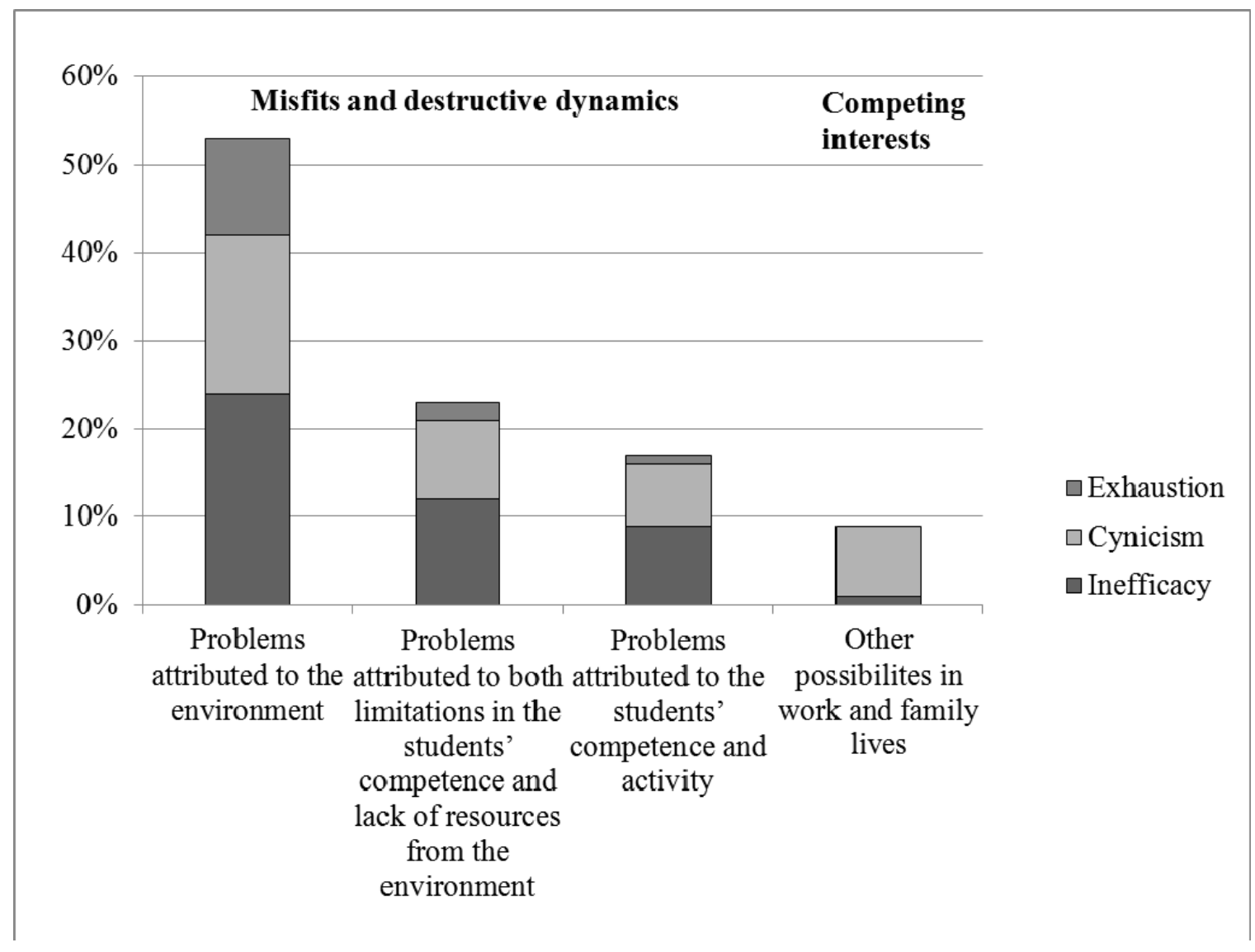

Figure 3: The forms of disengagement and the perceived destructive dynamics between the doctoral students and their working environments and competing interests.

Further investigation revealed that when the students described misfits relating to their environment they often emphasized struggles and conflicts within the scholarly community. They reported that the scholarly community had a great deal of control over their research work while leaving them completely alone to find the right way to proceed. They felt a lack of belonging due to many of their efforts to become members of the community being rejected and could not make sense of the community's practices and rules. Thus they had become cynical and felt a sense of inefficacy in their doctoral work. The students also sometimes associated their alienation with the demands of their full-time work or lack of support from family as well as changes in their personal lives. One of the students talked about struggles faced within the scholarly community:

This is not any competition, instead it is a systematic disparagement...The atmosphere is quite hostile...For instance, one professor from another field came to tell me that there is no sense to my work, that my approach was wrong... and I was astonished how anyone could say something so inappropriate and in such a crushing way to a beginner, to a doctoral student...

In the episodes where students referred to misfits that were attributed to both limitations in the environment and shortcomings in the students, they often highlighted the tensions in the supervisory relationship. Their supervisors' over-demanding requirements, lack of support and interest as well as destructive feedback were of no help with respect to their own lack of interest and the competences and skills needed to carry out their work. Hence the students experienced a feeling of being alone and without support. In addition, in episodes where the students faced inconsistent requirements or problematic interactions with other researchers and perceived themselves as lack- 
ing the necessary competences, they also felt unsupported as well as ineffective as novice researchers and cynical towards their doctoral work. One student described the limitations in both the supervisory relationship and his/her activities as follows:

I felt that these seminars were too broad, too many diverse topics and I was not interested...I was only interested in what I could get out of them for myself. But I did not get the kind of support I needed in them. These seminars were sometimes mind-numbing and I had no motivation. Then it was easy to leave them behind, and the same also happened with the research work...

When the students perceived the misfit to be a result of them lacking the competence to meet the requirements of the environment, they especially referred to problems in the research process. They were given opportunities to progress in their research, such as writing or presenting papers, but thought that they lacked the required research competences or motivation to meet the demands associated with the new possibilities, and hence they felt ineffective in their doctoral work. As one of the students recounted:

I had a chance to present my research work in a very excellent setting. But I felt that I had nothing to say, so I had to cancel the presentation, I did not have the courage to go there. I felt that I had written the abstract somehow incorrectly and they might have thought that I had something more to give than I really had. I felt that I really could not do it.

When the students mentioned competing interests they emphasized that these resulted from their rivaling careers or family lives. These rivaling interests occupied them more, thus reducing their interest in earning a doctoral degree. When attending to their families or professional careers they felt very distant from their doctoral studies. One student put it as follows:

My child was born and there came a long period where nothing happened in the research besides little things like following what others were doing. It actually went in the opposite direction, I could not do anything. I was a couple of years at home, this ruined my plans, and I put my thesis aside.

\section{Reflections on the Method and its Limitations}

In this study we relied on a qualitative approach (Marshall \& Rossman, 1995; Miles \& Huberman, 1994) inspired by phenomenography (Marton, 1986; Van Rossum \& Hamer, 2010). In applying this approach we explored doctoral students' experiences of disengagement from their doctoral process, variations in such experiences as well as the dynamics between the students and their environments during these experiences. Using an abductive analysis strategy (Coffey \& Atkinson, 1996; Haig, 2005; Levin-Rozalis, 2004; Morgan, 2007) enabled us to focus on variations of the experiences at the collective level instead of focusing solely on individuals ( $\AA$ kerlind, 2005).

The interview data were collected from 16 behavioral sciences doctoral students from a large research-intensive Finnish University. Because of the distinctive features of the discipline (Lindblom-Ylänne, Trigwell, Nevgi, \& Ashwin, 2006; McCune \& Hounsell, 2005) and the limited sample size, generalizing the results to other disciplines and in other countries should be done with caution. On the other hand, the semi-structured interviews provided rich data that could be used to effectively identify and analyze the episodes that were associated with doctoral students' disengagement from their doctoral work. Accordingly, they also allowed for an exploration of disengaging episodes embedded in a variety of practices in academia. Hence, these findings have theoretical transferability in terms of further studies in the field of doctoral student disengagement research. 
Certain challenges are involved in using a retrospective approach (Cox \& Hassard, 2007). The participants' experiences and their overall life situations were often difficult to recall and sum up in a single interview (Kvale, 2007). Accordingly, the retrospection was likely to have affected the data, including a generalization of experiences. In order to better support the participants' retrospection of their subjective experiences, each interview began with the student visualizing her/his own doctoral process and identifying the most significant episodes within the visualization. Using a retrospective approach and semi-structured interviews also had its advantages (Cox \& Hassard, 2007). The reflective and process-oriented design gave the participants an opportunity to reflect on their doctoral journey and identify significant events in it. This resulted in rich data including themes the researchers could not have anticipated. It also ensured that the participants recalled and reported only significant events and episodes. However, further research, particularly with a longitudinal design, is needed to examine the development of disengagement over a more extended period of time.

Although more studies on doctoral student disengagement are needed, the present findings concerning behavioral sciences doctoral students can be considered a valuable addition to current knowledge in the field of higher education, particularly doctoral education.

\section{Discussion and Conclusions}

The dynamics that contribute to disengagement from the doctoral process are rarely studied in doctoral education. The present research was carried out within the context of prolonged doctoral studies and, therefore, provides insight into the phenomenon by shedding light on behavioral doctoral students' various disengaging experiences and the dynamics between the students and their working environment during these experiences. The results revealed varying disengaging experiences including inefficacy, cynicism, and sometimes exhaustion. Similar experiences have been typically studied within work-related settings (Hakanen et al., 2006; Maslach et al., 2001; Salanova et al., 2010; Schaufeli et al., 2002). Our findings suggest that conducting doctoral work does not mean only taking courses, studying the domain, and conducting research; it is also very much academic work within a scholarly community that doctoral students as novice researchers are engaged in.

Further, our study suggests that even though the contexts of the disengaging experiences and the quality of the destructive dynamics varied, the students often saw the problem as resulting from an overly controlling or alienating scholarly community. The results support other recent findings indicating that a misfit between the person and the environment increases the risk of negative work-related experiences and work drive (Hakanen et al., 2006; Pyhältö, Pietarinen, \& SalmelaAro, 2011). These findings imply that the person-environment fit model that we used (Edwards et al., 2006; Kristof, 1996) provided a functional framework for exploring the dynamic interplay between the students and their various environments that contributed to their disengagement from doctoral work.

In particular, our results are in line with previous studies on doctoral education which indicate that perceived misfits between doctoral students and their scholarly communities are likely to contribute to students' negative experiences and weaken their persistence (Golde, 2005; Hoskins \& Goldberg, 2005; Tinto, 1993). The supervisory relationship has been identified as one of the main determinants of student satisfaction or distress (Ives \& Rowley, 2005; Jairam \& Kahl Jr., 2012; Zhao, Golde, \& McCormick, 2007). In our study the supervisory relationship emerged as one of the important contexts that the students associated with their disengagement. However, the study also provided new insight in this area by demonstrating how the students perceived events in their larger scholarly community, including problematic interactions with faculty and department members as well as members of international research communities, as significant sources of their disengagement. A reason for this may be that the students might have been less familiar 
with the practices of the larger scholarly community and more familiar with those involved in their own supervision and, hence, experienced more problems when interacting with other researchers than with their own supervisors.

There is evidence of destructive friction in student-scholarly community interaction as well as feeling outside the community reducing doctoral students' positive and satisfying experiences as well as persistence in their studies (Ali \& Kohun, 2006; Deem \& Brehony, 2000; Lovitts, 2001; Spaulding \& Rockinson-Szapkiw, 2012). The results of our study provide new insights by demonstrating how dysfunctional interaction between students and the members of their scholarly communities as well as students' experiences of not belonging were significant in terms of students' disengagement from the doctoral process. Along with experiences of not belonging, the sense of lacking the competence to conduct doctoral work and having little control over it were related to the experienced disengagement. The sense of not belonging that behavioral science doctoral students' possess may have to do with the nature of the research in their discipline. As part of the soft sciences, the behavioral sciences are sometimes characterized by solitary research work in libraries, archives, or in the field (Lovitts, 2001). Such practices may not foster a sense of being a member of a scholarly community. However, not all doctoral students in behavioral sciences work on their own; there is an emerging tendency towards more collective research and supervisory practices. Our previous study (Vekkaila et al., 2012) on natural sciences doctoral students revealed more about engagement in this regard: the central finding was that students' participation in the research community's various activities triggered experiences of belonging that enhanced their doctoral processes.

Further, our results suggest that disengagement from the doctoral process is also possible when rivaling interests, with respect to careers or families, preoccupy them more than their thesis work, even though they may perceive that completing their thesis is possible. This may be because pursuing a $\mathrm{PhD}$ is a long-term process where the goal is distant. Hence, students may need the shortterm goals that other pathways may provide. This raises the question of how to better engage doctoral students in the doctoral process and scholarly community.

Our results imply that the quality of doctoral students' disengagement differs, and hence the means and practices to foster students' engagement in their doctoral research also need to be more diverse. For instance, doctoral students who themselves feel ineffective with respect to conducting their research may need support that makes them feel more competent as researchers. Students who have become cynical and feel that the doctoral work has lost its meaning, on the other hand, may need support in finding the personal significance of their work and in gaining a sense of control over it.

Furthermore, the results indicate that the quality of the interplay between students and the scholarly community matters. Hence, both doctoral educators and doctoral students need to find ways to support the constructive interplay between students and the scholarly community and arenas in which to do so. Spaulding and Rockinson-Szapkiw's (2012) research on persistence factors associated with the successful completion of a doctoral degree implies that in doctoral education both academic match and social-personal match between doctoral students and their scholarly community are important. They point to certain aspects that individuals who are considering doctoral studies, and students who have already begun the process, should pay attention to in order to enhance the match between themselves and their scholarly community. They recommend that students should choose a doctoral program that meets their unique needs, as well as consider the social and integration practices of the education program, the dynamics of the scholarly community's interaction, along with faculty members' personalities and communication styles in addition to their expertise and experience. It follows that doctoral students' engagement can be reinforced by fostering constructive experiences in their everyday academic interactions. This can be done by facilitating their participation in collaborative academic practices, for instance. An ex- 
ample of practices that may promote students' engagement is a learning community formed around certain academic activities (Zhao \& Kuh, 2004) which involve active and collaborative learning techniques, interaction, and academic challenges (Bresó, Schaufeli, \& Salanova, 2011; Umbach \& Wawrzynski, 2005). This could be applied in doctoral education to foster participation, for instance through peer or writing groups (Aitchison \& Lee, 2006; Boud \& Lee, 2005; Lonka, 2003). Ali and Kohun (2007) have also developed a framework that can be applied when dealing with feelings of isolation in doctoral programs. They suggest, for instance, that by clarifying the dissertation requirements, providing administrative support, and making structured advisor selection possible as well as face-to-face communication, doctoral students' sense of belonging can be increased.

In addition, doctoral students may need support in interpreting the scholarly world and its requirements. It is the responsibility of more experienced academics, such as supervisors and senior researchers of research groups, to share ways of interpreting the scholarly world and coping with academic tension and conflict. The development of practices and ways to promote experiences of engagement during the doctoral journey would also simultaneously buffer doctoral students and help them cope with negative experiences, conflicts, and demands imposed by the environments not only within but also outside the scholarly community.

In the present study we were able to provide insight into behavioral sciences doctoral students' experiences of disengagement from their theses process. However, disengagement is not an experience that exists in a vacuum or which is disconnected from engagement. The environments of doctoral work also provide resources for engagement and developing positive drive (Stubb et al., 2011; Vekkaila et al., 2012). However, engagement itself was not the focus of the present study, and further research on engagement in doctoral work is needed. Hence, in future research we intend do look at engagement in behavioral sciences doctoral students who conduct their doctoral theses within a top-level research community.

\section{References}

Aitchison, C., \& Lee, A. (2006). Research writing: Problems and pedagogies. Teaching in Higher Education, 11(3), 265-278.

Ali, A., \& Kohun, F. (2006). Dealing with isolation feelings in IS doctoral programs. International Journal of Doctoral Studies, 1, 21-33. Retrieved from http://www.ijds.org/Volume1/IJDSv1p021-033Ali13.pdf

Ali, A., \& Kohun, F. (2007). Dealing with social isolation to minimize doctoral attrition - A four stage framework. International Journal of Doctoral Studies, 2, 33-49. Retrieved from http://www.ijds.org/Volume2/IJDSv2p033-049Ali28.pdf

Appel, M., \& Dahlgren, L. (2003). Swedish doctoral students' experiences on their journey towards a PhD: Obstacles and opportunities inside and outside the academic building. Scandinavian Journal of Educational Research, 47(1), 89-110.

Baker, V. L., \& Lattuca, L. R. (2010). Developmental networks and learning: Toward an interdisciplinary perspective on identity development during doctoral study. Studies in Higher Education, 35(7), 807827.

Boud, D., \& Lee, A. (2005). Peer learning as pedagogic discourse for research education. Studies in Higher Education, 30(5), 501-516.

Bozeman, B., Dietz, J. S., \& Gaughan, M. (2001). Scientific and technical human capital: An alternative model for research evaluation. International Journal of Technology Management, 22(7-8), 716-740.

Bresó, E., Schaufeli, W. B., \& Salanova, M. (2011). Can a self-efficacy-based intervention decrease burnout, increase engagement, and enhance performance? A quasi-experimental study. Higher Education, 61(4), 339-355. 
Brew, A. (2001). Conceptions of research: A phenomenographic study. Studies in Higher Education, 26(3), 271-285.

Brew, A., Boud, D., \& Namgung, S.U. (2011). Influences on the formation of academics: The role of the doctorate and structured development opportunities. Studies in Continuing Education, 33(1), 51-66.

Bryman, A. (2004). Social research methods (2nd ed.). Oxford, UK: Oxford University Press.

Carini, R. M., Kuh, G., \& Klein, S. P. (2006). Student engagement and student learning: Testing the linkages. Research in Higher Education, 47(1), 1-32.

Coffey, A., \& Atkinson, P. (1996). Making sense of qualitative data. Complementary research strategies. Thousands Oaks, CA: Sage.

Cox, J. W., \& Hassard, J. (2007). Ties to the past in organization research: A comparative analysis of retrospective methods. Organization, 14(4), 475-497.

Creswell, J. W. (2003). Research design. Qualitative, quantitative and mixed methods approaches (2nd ed.). Thousand Oaks: Sage.

Decision of vice-chancellor 6/2011 [in Finnish]. Retrieved from http://savotta.helsinki.fi/halvi/asianhallinta/dynasty/Rehtori.nsf?OpenDatabase .

Decision of vice-chancellor 234/2006 [in Finnish]. Retrieved from http://notes.helsinki.fi/halvi/hallinto/Rehtorin.nsf/dc887e3b5230caa0c225685400395d44/1ac1be24290 ff074c2257258002bd662

Deem, R., \& Brehony, K. J. (2000). Doctoral students access to research cultures - Are some more unequal than others? Studies in Higher Education, 25(2), 149-165.

Demerouti, E., Bakker, A. B., Nachreiner, F., \& Schaufeli, W. B. (2001). The job demands - Resources model of burnout. Journal of Applied Psychology, 86(3), 499-512.

Edwards, J. R., Cable, D. M., Williamson, I. O., Schurer Lambert, L., \& Shipp, A. J. (2006). The phenomenology of fit: Linking the person and environment to the subjective experience on person environment fit. Journal of Applied Psychology, 91(4), 802-827.

Finland's Council of State's regulation of university degrees 645/1997 [In Finnish]. Retrieved from http://www.finlex.fi/fi/laki/alkup/2004/20040794

Fredricks, J. A., Blumenfeld, P. C., \& Paris, A. H. (2004). School engagement: Potential of the concept, state of evidence. Review of Educational Research, 74(1), 59-109.

Gardner, S. K. (2007). "I heard it through the grapevine": Doctoral student socialization in chemistry and history. Higher Education, 54(5), 723-740.

Golde, C. M. (1998). Beginning graduate school: Explaining first-year doctoral attrition. New Directions for Higher Education, 101, 55-64.

Golde, C. M. (2005). The role of the department and discipline in doctoral student attrition: Lessons from four departments. The Journal of Higher Education, 76(6), 669-700.

Haig, B. D. (2005). An abductive theory of scientific method. Psychological Methods, 10(4), 371-388.

Hakanen, J. J., Bakker, A. B., \& Schaufeli, W. B. (2006). Burnout and work engagement among teachers. Journal of School Psychology, 43(6), 495-513.

Harry, B., Sturges, K. M., \& Klingner, J. K. (2005). Mapping the process: An exemplar of process and challenge in grounded theory analysis. Educational Researcher, 34(2), 3-13.

Holland, J. (1985). Making vocational choices: A theory of vocational personalities and work environments (2nd ed.). Englewood Cliffs, NJ: Prentice-Hall.

Holley, K. A. (2011). A cultural repertoire of practices in doctoral education. International Journal of Doctoral Studies, 6, 79-94. Retrieved from http://ijds.org/Volume6/IJDSv6p079-094Holley312.pdf 
Hoskins, C. M. \& Goldberg, A. D. (2005). Doctoral student persistence in counselor education programs: Student-program match. Counselor Education and Supervision, 44(3), 175-188.

Hyun, J. K., Quinn, B. C., Madon, T., \& Lustig, S. (2006). Graduate student mental health: Needs assessment and utilization of counseling services. Journal of College Student Development, 47(3), 247-266.

Ives, G., \& Rowley, G. (2005). Supervisor selection or allocation and continuity of supervision: Ph.D. students' progress and outcomes. Studies in Higher Education, 30(5), 535-555.

Jairam, D., \& Kahl Jr., D. H. (2012). Navigating the doctoral experience: The role of social support in successful degree completion. International Journal of Doctoral Studies, 7, 311-329. Retrieved from http://ijds.org/Volume7/IJDSv7p311-329Jairam0369.pdf

Kristof, A. L. (1996). Person-organization fit: An integrative review of its conceptualizations, measurement, and implications. Personnel Psychology, 49(1), 1-49.

Kurtz-Costes, B., Helmke, A. L., \& Ülkü-Steiner, B. (2006). Gender and doctoral studies: The perceptions of $\mathrm{PhD}$ students in an American university. Gender \& Education, 18(2), 137-155.

Kvale, S. (1996). Interviews. An introduction to qualitative research interviewing. London: Sage.

Kvale, S. (2007). Doing interviews. London: Sage.

Lave, J., \& Wenger, E. (1991). Situated learning: Legitimate peripheral participation. Cambridge: Cambridge University Press.

Lee, C. J. (2009). The experience of nurse faculty members enrolled in doctoral study. International Journal of Doctoral Studies, 4, 59-75. Retrieved from http://www.ijds.org/Volume4/IJDSv4p059075Lee255.pdf

Leech, N. L. (2012). Educating knowledgeable and skilled researchers in doctoral programs in schools of education: A new model. International Journal of Doctoral Studies, 7, 19-37. Retrieved from http://ijds.org/Volume7/IJDSv7p019-037Leech325.pdf

Levine, A. (2007). Educating researchers. Washington, DC: The Education Schools Project.

Levin-Rozalis, M. (2004). Searching for the unknowable: A process of detection - Abductive research generated by projective techniques. International Journal of Qualitative Methods, 3(2), 1-18.

Lindblom-Ylänne, S., \& Lonka, K. (2000). Interaction between learning environment and expert learning. Lifelong Learning in Europe, 5(2), 90-97.

Lindblom-Ylänne, S., Trigwell, K., Nevgi, A., \& Ashwin, P. (2006). How approaches to teaching are affected by discipline and teaching context. Studies in Higher Education, 31(3), 285-298.

Lonka, K. (2003). Helping doctoral students to finish their theses. In L. Björk, G. Bräuer, L. Rienecker, G. Ruhmann \& P. Stray Jørgensen (Eds.), Teaching academic writing across Europe (pp. 113-131). Dordrecht, The Netherlands: Kluwer University Press.

Lovitts, B. E. (2001). Leaving the Ivory Tower: The causes and consequences of departure from doctoral study. Lanham, MD: Rowman and Littlefield.

Lovitts, B. E. (2005). Being a good course-taker is not enough: A theoretical perspective on the transition to independent research. Studies in Higher Education, 30(2), 137-154.

Marshall, C., \& Rossman, G. B. (1995). Designing qualitative research (2nd ed.). Thousand Oaks. CA: Sage.

Marton, F. (1986). Phenomenography - A research approach to investigating different understandings of reality. Journal of Thought, 3(21), 28-49.

Maslach, C., Schaufeli, W. B., \& Leiter, M. P. (2001). Job burnout. Annual Review of Psychology, 52(1), 397-422. 
McAlpine, L., \& Amundsen, C. (2008). Academic communities and developing identity: The doctoral student journey. In P. Richards (Ed.), Global issues in higher education (pp. 57-83), NY: Nova Publishing.

McAlpine, L., Jazvac-Martek, M., \& Hopwood, N. (2009). Doctoral student experience in education: Activities and difficulties influencing identity development. International Journal for Researcher Development, 1(1), 97-109.

McAlpine, L., \& Norton, J. (2006). Reframing our approach to doctoral programs: An integrative framework for action and research. Higher Education Research \& Development, 25(1), 3-17.

McCune, V., \& Hounsell, D. (2005). The development of students' ways of thinking and practicing in three final-year biology courses. Higher Education, 49(3), 255-289.

Miles, M. B., \& Huberman, A. M. (1994). Qualitative data analysis (2nd ed.). Thousand Oaks, CA: Sage.

Mills, J., Bonner, A., \& Francis, K. (2006). The development of constructivist grounded theory. International Journal of Qualitative Methods, 5(1), 25-35.

Morgan, D. L. (2007). Paradigms lost and pragmatism regained: Methodological implications of combining qualitative and quantitative methods. Journal of Mixed Methods Research, 1(1), 48-76.

O’Donnell, V., Tobbell, J., Lawthom, R., \& Zammit, M. (2009). Transition to postgraduate study: Practice, participation and the widening participation agenda. Active Learning in Higher Education, 10(1), 2640 .

Patton, M. Q. (1990). Qualitative research and evaluation methods (2nd ed.). Newbury Park, CA: Sage.

Pekrun, R., Goetz, T., Frenzel, A. C., Barchfeld, P., \& Perry, R. P. (2011). Measuring emotions in students' learning and performance: The Achievement Emotions Questionnaire (AEQ). Contemporary Educational Psychology, 36(1), 36-48.

Protivnak, J. J., \& Foss, L. L. (2009). An exploration of themes that influence the counselor education doctoral student experience. Counselor Education \& Supervision, 48(4), 239-256.

Pyhältö, K., \& Keskinen, J. (2012). Doctoral students' sense of relational agency in their scholarly communities. International Journal of Higher Education, 1(2), 136-149.

Pyhältö, K., Pietarinen, J., \& Salmela-Aro, K. (2011). Teacher-working-environment fit as a framework for burnout experienced by Finnish teachers. Teaching and Teacher Education, 27(7), 1101-1110.

Pyhältö, K., Stubb, J., \& Lonka, K. (2009). Developing scholarly communities as learning environments for doctoral students. International Journal for Academic Development, 14(3), 221-232.

Pyhältö, K., Stubb, J., \& Tuomainen, J. (2011). International evaluation of research and doctoral education at the University of Helsinki - To the top and out to society. Summary report on doctoral students' and principal investigators' doctoral training experiences. Retrieved from http://wiki.helsinki.fi/display/evaluation2011/Survey+on+doctoral+training

Reavey, P. (2011). The return to experience. Psychology and the visual. In P. Reavey (Ed.), Visual methods in psychology: Using and interpreting images in qualitative research (pp. 1-14). New York, NY: Routledge.

Reeve, J., Jang, H., Carrell, D., Jeon, S., \& Barch, J. (2004). Enhancing students' engagement by increasing teachers' autonomy support. Motivation and Emotion, 28(2), 147-169.

Rose, G. (2007). Visual methodologies. An introduction to the interpretation of visual materials (2nd ed.). London: Sage.

Sainio, J. (2010). Asiantuntijana työmarkkinoille - Vuosina 2006 ja 2007 tohtorin tutkinnon suorittaneiden työllistyminen ja heidän mielipiteitään tohtorikoulutuksesta [Experts for the labour market - The employment of doctors who earned their doctoral degree in 2006-2007 and their perceptions of doctoral training ]. Tampere: Kirjapaino Hermes Oy. 
Salanova, M., Schaufeli, W. B., Martı'nez, I., \& Bresó, E. (2010). How obstacles and facilitators predict academic performance: The mediating role of study burnout and engagement. Anxiety, Stress, \& Coping, 23(1), 53-70.

Schaufeli, W. B., \& Bakker, A. B. (2004). Job demands, job resources, and their relationship with burnout and engagement: A multisample study. Journal of Organizational Behavior, 25(3), 293-315.

Schaufeli, W. B., Salanova, M., González-Romá, V., \& Bakker, A. B. (2002). The measurement of engagement and burnout: A two sample confirmatory factor analytic approach. Journal of Happiness Studies, 3(1), 71-92.

Schmitt, N., Oswald, F. L., Friede, A., Imus, A., \& Merritt, S. (2008). Perceived fit with an academic environment: Attitudinal and behavioral outcomes. Journal of Vocational Behavior, 72(3), 317-335.

Schreiner, L. A., Noel, P., Anderson, E., \& Cantwell, L. (2011). The impact of faculty and staff on highrisk college student persistence. Journal of College Student Development, 52(3), 321-338.

Spaulding, L. S., \& Rockinson-Szapkiw, A. J. (2012). Hearing their voices: Factors doctoral candidates attribute to their persistence. International Journal of Doctoral Studies, 7, 199-219. Retrieved from http://ijds.org/Volume7/IJDSv7p199-219Spaulding334.pdf

Stubb, J., Pyhältö, K., \& Lonka, K. (2011). Balancing between inspiration and exhaustion: PhD students' experienced socio-psychological well-being. Studies in Continuing Education, 33(1), 33-50.

Tinto, V. (1993). Leaving college: Rethinking the causes and cures of student attrition (2nd ed.). Chicago: The University of Chicago Press.

Turner, G., \& McAlpine, L. (2011). Doctoral experience as researcher preparation: Activities, passion, status. International Journal for Researcher Development, 2(1), 46-60.

Umbach, P. D., \& Wawrzynski, M. R. (2005). Faculty do matter: The role of college faculty in student learning and engagement. Research in Higher Education, 46(2), 153-184.

Van Rossum, J. E., \& Hamer, R. N. (2010). The meaning of learning and knowing. Sense Publisher: Rotterdam, The Netherlands.

Vekkaila, J., Pyhältö, K., Hakkarainen, K., Keskinen, J., \& Lonka, K. (2012). Doctoral students' key learning experiences in the natural sciences. International Journal for Researcher Development, 3(2), 154183.

Vermunt, J. D., \& Verloop, N. (1999). Congruence and friction between learning and teaching. Learning and Instruction, 9(3), 257-280.

Wao, H. O., \& Onwuegbuzie, A. J. (2011). A mixed research investigation of factors related to time to the doctorate in Education. International Journal of Doctoral Studies, 6, 115-134. Retrieved from http://ijds.org/Volume6/IJDSv6p115-134Wao320.pdf

White, J., \& Nonnamaker, J. (2008). Belonging and mattering. How science doctoral students experience community. NASPA Journal, 45(3), 350-372.

Zhao, C.-M., Golde, C. M., \& McCormick, A. C. (2007). More than a signature: How advisor choice and advisor behaviour affect doctoral student satisfaction. Journal of Further and Higher Education, 31(3), 263-281.

Zhao, C., \& Kuh, G. D. (2004). Adding value: Learning communities and student engagement. Research in Higher Education, 45(2), 115-138.

Åkerlind, G. S. (2005). Variation and commonality in phenomenographic research methods. Higher Education Research \& Development, 24(4), 321-334. 


\section{Biographies}

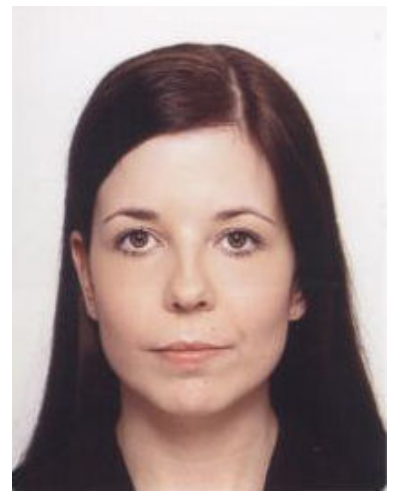

Jenna Vekkaila, M.A. (Educ.), is a PhD student in the Research Unit for Teaching and Learning Sciences at the Department of Teacher Education, University of Helsinki, Finland. Her thesis concerns student engagement in the doctoral process and the dynamic interplay between doctoral students and their learning/working environments. She can be reached at jenna.vekkaila@helsinki.fi

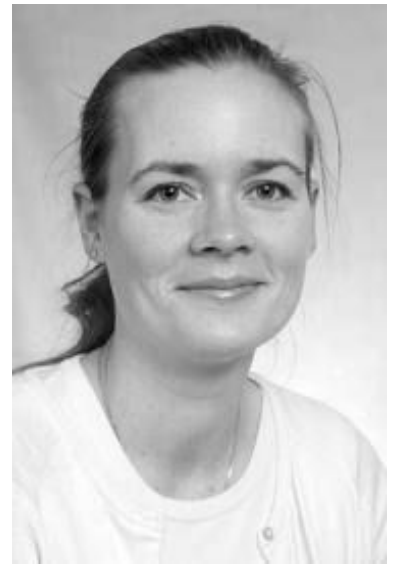

Kirsi Pyhältö, $\mathrm{PhD}$, is an adjunct professor and senior pedagogical university lecturer in higher education at the Centre for Research and Development in Higher Education, University of Helsinki, Finland. Her research interests include postgraduate education, learning and professional development in higher education, and agency and wellbeing in basic education. She can be reached at kirsi.pyhalto@helsinki.fi.

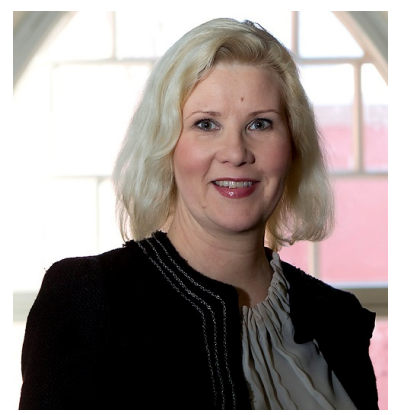

Kirsti Lonka, $\mathrm{PhD}$, is a professor of educational psychology and vice dean of the Faculty of Behavioural Sciences, University of Helsinki, Finland. Her research interests include university student learning, academic writing, postgraduate education, medical education, and teacher education. She can be reached at kirsti.lonka@helsinki.fi 